PENERAPAN PROBLEM BASED LEARNING SEBAGAI UPAYA

MENINGKATKAN SIKAP ILMIAH SISWA KELAS V DALAM

PEMBELAJARAN IPA DI SEKOLAH DASAR

\title{
IMPLEMENTATION OF PROBLEM BASED LEARNING IN EFFORTS \\ TO INCREASE CLASS V SCIENTIFIC ATTITUDE IN NATURAL SCIENCE LEARNING IN PRIMARY SCHOOL
}

\author{
Wikut Deniarti \\ SDN 1 Sambirata, Cilongok Purwokerto \\ Email: denniawikut@yahoo.co.id \\ Anang Masduki \\ Program Studi Ilmu Komunikasi UAD Yogyakarta \\ Email: anang_masduki@yahoo.com
}

\begin{abstract}
This research purpose to increase the scientific attitude in the fifth grade students learning sains through the application of Problem Based Learning in Elementary School Caturtunggal 7 Depok Sleman, Yogyakarta. The subject of this research is the fifth grade elementary school students Caturtunggal 7 Depok, Sleman, amounting to 16 students. This type of research is Classroom action research are held in two cycles of action. Data collection instruments used were sheets of observation, interviews, and camera digital. The validity of the instruments is done through expert judgment. The data have been collected were analyzed by descriptive quantitative and qualitative. Quantitative descriptive analysis was used to compare the percentage of the value of each student step by step. The results showed that with applied Problem Based Learning in sains learning can increase students scientific attitude fifth grade in Elementary school Caturtunggal 7 Depok Sleman, Yogyakarta. This is indicated by the increasing number of students who scored higher than $75 \%$ of the initial condition until the second cycle. At the beginning there were 4 students (25\%) reached KKM. The average grade achieved is 51.93. In cycle I have 9 students $(56.25 \%)$ reached KKM. The average grade achieved was 66. In the second cycle there were 13 students $(81.25 \%)$ reached KKM. The average grade achieved is 77.56 .
\end{abstract}

\section{ABSTRAK}

Penelitian ini bertujuan untuk meningkatkan sikap ilmiah pada siswa kelas lima belajar sains melalui penerapan Problem Based Learning di Sekolah Dasar Caturtunggal 7 Depok Sleman, Yogyakarta. Subyek penelitian ini adalah siswa SD kelas lima Caturtunggal 7 Depok, Sleman, sebesar 16 siswa. Jenis penelitian ini adalah penelitian tindakan kelas yang diadakan dalam dua siklus tindakan. Instrumen pengumpulan data yang digunakan adalah lembar observasi, wawancara, dan kamera digital. Validitas instrumen dilakukan melalui penilaian ahli. Data yang telah dikumpulkan dianalisis dengan deskriptif kuantitatif dan 
kualitatif. Analisis deskriptif kuantitatif digunakan untuk membandingkan persentase dari nilai setiap langkah siswa demi langkah. Hasil penelitian menunjukkan bahwa dengan diterapkan Problem Based Learning di sains pembelajaran dapat meningkatkan siswa kelas lima sikap ilmiah di sekolah SD Caturtunggal 7 Depok Sleman, Yogyakarta. Hal ini ditunjukkan dengan meningkatnya jumlah siswa yang mendapat nilai lebih tinggi dari $75 \%$ dari kondisi awal sampai siklus kedua. Pada awalnya ada 4 siswa (25\%) mencapai KKM. Rata-rata nilai yang dicapai adalah 51,93. Pada siklus I memiliki 9 siswa $(56,25 \%)$ mencapai KKM. Rata-rata nilai yang dicapai adalah 66. Pada siklus II ada 13 siswa $(81,25 \%)$ mencapai KKM. Rata-rata nilai yang dicapai adalah 77,56.

Kata kunci: Pembelajaran Berbasis Masalah, Sikap Ilmiah, dan Sains

\section{Pendahuluan}

Sesuai Undang-Undang RI Nomor 14 tahun 2005 tentang Guru dan Dosen (BAB IV, Pasal 10) disebutkan bahwa seorang guru harus memiliki empat kompetensi, salah satunya adalah kompetensi pedagogik. Di dalam kompetensi tersebut seorang guru harus memahami peserta didiknya secara mendalam dan menyelenggarakan pembelajaran yang mendidik. Pemahaman terhadap peserta didik meliputi penguasaan karakteristik peserta didik dari aspek fisik, moral, spiritual, sosial, kultural, emosional, dan intelektual, sedangkan pembelajaran yang mendidik meliputi kemampuan merancang, mengimplementasikan, menilai proses, dan hasil pembelajaran serta melakukan perbaikan secara berkelanjutan. Jadi jika guru tidak menguasai kompetensi tersebut hal ini akan berdampak pada penjabaran kemampuan-kemampuan dalam standar kompetensi dan kompetensi dasar yang harus dikuasai siswa. Penjabaran kemampuan yang kurang tepat akan mempengaruhi proses pembelajaran yang kurang membangun kompetensi siswa, khususnya dalam pembelajaran IPA. Pada dasarnya karena pembelajaran IPA lebih menekankan pada pemberian pengalaman langsung untuk membangun dan mengembangkan kompetensi. Tujuannya agar peserta didik mampu menjelajahi dan memahami alam sekitar secara ilmiah.

Menurut Patta Bundu (2006:4) pembelajaran IPA terdiri dari tiga dimensi utama yang saling berkaitan erat. Dimensi pertama adalah "the content of science, the science concept, and our scientific knowledge" (isi materi IPA, konsep IPA, dan pengetahuan ilmiah). Dimensi pertama disebut produk ilmiah atau produk 
sains. Dimensi kedua disebut proses ilmiah atau proses sains. Mempelajari kegiatan yang harus dimiliki dalam memecahkan masalah yang dihadapi seharihari serta membekali peserta didik dengan keterampilan berbagai aspek kehidupan di masa yang akan datang. Dimensi ketiga terfokus pada "the characteristic attitudes and dipositions of science" (karakteristik dan pandangan sains). Dimensi ini disebut juga sikap ilmiah atau sikap sains yang sangat penting untuk menguasai dua dimensi lainnya.

Berdasarkan uraian di atas dapat dikatakan bahwa IPA memberi bekal pada siswa meliputi pengetahuan, keterampilan, dan sikap ilmiah. Hal tersebut diperlukan untuk memahami dan menyesuaikan diri terhadap fenomena dan perubahan-perubahan di lingkungan sekitar dirinya, untuk membangun dan mengembangkan kompetensinya. Siswa memiliki bekal dan kesiapan dengan sikap ilmiahnya untuk memecahkan permasalahan yang dihadapi dalam kehidupan sehari-hari.

Gage (dalam Patta Bundu, 2006:39) mengemukakan bahwa ada empat sikap ilmiah yaitu curiosity, inventiveness, critical thinking, persistence. Keempat sikap ini sebenarnya tidak dapat dipisahkan antara satu dengan yang lainnya karena saling melengkapi. Sikap ingin tahu (curiosity) mendorong akan penemuan sesuatu yang baru (inventiveness) yang dengan berpikir kritis (critical thinking) akan meneguhkan pendirian (persistence) dan berani untuk berbeda pendapat.

Seperti yang sudah di uraikan di atas bahwa sikap ilmiah yang terdiri dari empat indikator memang sangat diperlukan dalam pembelajaran IPA. Tujuannya agar siswa dapat memecahkan permasalahan yang dihadapi dalam kehidupan sehari-hari. Winaputra (dalam Usman Samatowa, 2006:3) menyatakan bahwa pembelajaran IPA tidak hanya kumpulan pengetahuan tentang benda atau makhluk hidup, tetapi merupakan cara kerja, cara berpikir, dan cara memecahkan masalah. IPA diajarkan untuk meneliti masalah-masalah yang ada di sekitar melalui kerja ilmiah yang disebut metode ilmiah. Metode ilmiah inilah dalam pembelajaran IPA dapat membudayakan sikap ilmiah kepada siswa.

Menurut Patta Bundu (2006:3) pembelajaran IPA pada mayoritas di SD selama ini, 1) masih banyak guru yang sangat menekankan pembelajaran pada 
faktor ingatan, 2) sangat kurang palaksanaan praktikum, dan 3) fokus penyajian dengan ceramah yang mengakibatkan kegiatan sangat terbatas, tidak lebih dari mendengarkan dan menyalin. Pemaparan di atas dapat diartikan bahwa pembelajaran IPA lebih menekankan pada penguasaan sejumlah fakta dan konsep. Hal tersebut bisa dikatakan bahwa, hal itu dapat juga menjadi faktor penyebab sikap ilmiah siswa rendah karena tidak adanya pembudayaan sikap ilmiah yang seharusnya bisa didapatkan melalui kinerja ilmiah.

Permasalahan yang diungkapkan di atas ternyata tidak jauh berbeda dengan permasalahan yang terjadi di SD Negeri Caturtunggal 7. Hasil pengamatan di kelas V di SD tersebut ditemukan bahwa sikap ilmiah siswa masih rendah. Indikasi rendahnya sikap ilmiah tersebut antara lain 1) rasa ingin tahu (curiosity) terhadap suatu pengetahuan lemah. Contohnya ketika guru sedang menjelaskan materi pelajaran banyak siswa yang tidak memperhatikan, terlihat masa bodoh, tidak peduli akan pengetahuan yang akan diperolehnya, sehingga siswa hanya sekedar menerima pengetahuan itu tanpa dicerna dan memikirkan kenapa pengetahuan itu perlu dan bermanfaat. Kondisi tersebut mewujudkan mayoritas siswa pasif; 2) siswa tidak terdorong akan penemuan (inventiveness) sesuatu yang baru karena kodisi siswa yang hanya memiliki pengetahuan sebatas yang diberikan guru, itu pun jika semua diterima siswa tanpa mencari pengetahuan yang lebih luas. Keadaan seperti itu membuat siswa tidak berpikir kritis (critical thinking); 3) tidak berpikir kritis menjadikan siswa hanya duduk diam; 4) tidak berani berpendapat atau berargumen karena pengetahuan yang sedikit. Contohnya jika guru mengajukan pertanyaan atau pernyataan siswa hanya diam, tidak ada yang berani berpendapat. Jika guru memberikan kesempatan anak untuk bertanya, tidak ada yang bertanya hanya diam saja. Diperparah lagi dengan kurang tepatnya guru dalam mengemas pembelajaran IPA yang menjadikan siswa merasa bosan dalam mengikuti pelajarannya sehingga tidak menarik. Hal ini menyebabkan anak kurang sungguh-sungguh dan tidak tekun mempelajari IPA. Pembelajarannya juga belum memanfaatkan pendekatan lingkungan. Masih jarang sekali guru mengajak siswa untuk berinteraksi langsung dengan lingkungan. Guru sebagian besar masih mempertahankan urutan-urutan dalam buku tanpa mempedulikan kesesuaian 
dengan lingkungan belajar siswa. Hal ini membuat pembelajaran tidak efektif, karena siswa kurang merespon terhadap pelajaran yang disampaikan.

Belajar IPA yang sebenarnya bukan merupakan penghafalan kata-kata yang bermakna, melainkan merupakan hasil asosiasi dari pengalaman (Patta, 2006 : 14). Belajar akan lebih bermakna jika anak mengalami apa yang dipelajarinya, bukan hanya mengetahuinya. Dari pengalamannya diharapkan anak dapat memahami IPA secara lebih mendalam dan dapat diingat dalam waktu yang relatif lama (long term). Oleh karena itu, guru perlu mengaplikasikan strategi pembelajaran yang melibatkan anak secara langsung dalam kegiatan belajar mengajar, khususnya dalam mengembangkan sikap ilmiah siswa SD. Strategi tersebut salahsatunya adalah dengan menggunakan metode pembelajaran Problem Based Learning.

Problem Based Learning selanjutnya disingkat PBL merupakan suatu metode atau cara pembelajaran, yang ditandai oleh adanya masalah nyata ( $a$ realworld problems), sebagai sebuah konteks bagi para pembelajar untuk belajar berpikir kritis dan keterampilan memecahkan masalah serta memperoleh pengetahuan. PBL memiliki lima tahap dalam pelaksanaannya yakni Penyampaian Ide (Ideas), Penyajian Fakta yang Diketahui (Known Facts), Mempelajari Masalah ( Learning Issues), Menyusun Rencana Tindakan (Action Plan), dan Evaluasi (Punaji Setyosari, 2009). Secara garis besar PBL menyajikan kepada siswa situasi masalah yang autentik dan bermakna yang dapat memberikan kemudahan kepada mereka untuk melakukan penyelidikan inkuiri. PBL berpusat kepada siswa mendorong inkuiri terbuka dan berpikir bebas yang dikemukakan dalam bentuk laporan, karya yang akan dijadikan bahan evaluasi sehingga membantu siswa untuk menjadi mandiri.

Berdasarkan alasan tersebut, maka guru perlu mengembangkan wawasan siswa dengan menstimulus masalah-masalah yang ada di masyrakat dan sekitar, dan mengembangkan sikap penemuannya melalui kerja ilmiah yang pada akhirnya membudayakan sikap ilmiah. Sehingga siswa mendapat kesempatan untuk mengembangkan sikap ilmiah. Pengembangan wawasan dan sikap ilmiah 
siswa diharapkan dapat diperkenalkan pada suatu cara atau kondisi pembelajaran yang dapat menumbuhkan rasa percaya diri, kreatif, inovatif, dan mandiri.

Untuk membantu siswa meningkatkan dan mengembangkan sikap ilmiah dalam pembelajaran IPA tentang masalah-masalah yang ada di masyarakat dan sekitar maka pendekatan yang digunakan oleh guru dalam proses belajar mengajarnya yaitu dengan pendekatan pembelajaran berbasis masalah (Problem Based Learning).

\section{Metode Penelitian}

Penelitian ini mengambil sasaran kepada siswa kelas V SDN Caturtunggal 7 Depok Sleman Yogyakarta, berjumlah 16 siswa. Penelitian ini menggunakan metode Penelitian Tindakan Kelas yang dilaksanakan dengan empat langkah yaitu:

\section{Perencanaan (Planning)}

Perencanaan merupakan langkah awal setelah diperoleh gambaran umum tentang kondisi, situasi pembelajaran di kelas dan lingkungannya dapat dikenali dengan baik. Tahap perencanaan meliputi :

a) Menetapkan peneliti mitra yaitu guru kelas V SD Negeri Caturtunggal 7 Depok Sleman Yogyakarta. Membangun kesepahaman antara peneliti dengan observer tentang konsep dan pelaksanaan Penelitian Tindakan Kelas, topik yang diangkat dalam proses pembelajaran, serta penentuan waktu pelaksanaan kegiatan Penelitian Tindakan Kelas.

b) Penentuan tindakan-tindakan yang diharapkan akan menghasilkan dampak ke arah perbaikan program.

c) Mengkaji kurikulum mata pelajaran IPA Kelas V untuk mengetahui standar kompetensi dan hasil belajar yang ditetapkan kurikulum pada topik Pesawat Sederhana. Menyusun rancangan umum pembelajaran, pemilihan metode dan instrumen penelitian untuk pengumpulan data yang berhubungan dengan rencana pelaksanaan pembelajaran beserta LKS, lembar observasi, faktor pendukung dan penghambat pelaksanaan selama pembelajaran IPA pada PTK berlangsung.

2. Tindakan (Action) 
Pada tahap pelaksanan tindakan mengacu pada langkah-langkah sesuai dengan Pendekatan Problem Based Learning :

3. Penyampaian ide (Ideas)

Pada tahap ini siswa melakukan brainstorming dibimbing oleh guru dengan pengetahuan awal siswa tentang Pesawat Sederhana. Kemudian siswa dibawa keluar kelas mengelilingi lingkungan sekolah. Selama perjalanan, siswa diminta untuk mengamati dan merekam kegiatan yang berkaitan dengan Pesawat sederhana. Setelah selesai siswa kembali ke dalam kelas.

4. Penyajian fakta yang diketahui (Known Facts)

Pada tahap ini siswa diajak untuk mendata hasil perjalanan ke lingkungan sekolah dikumpulkan berupa kertas kecil yang telah ditulisi kejadian-kejadian yang terjadi berkaitan dengan Pesawat Sederhana. Kemudian siswa dikelompokkan menjadi beberapa kelompok. Setelah itu mereka diajak mendata sejumlah fakta pendukung sesuai dengan masalah yang telah diajukan.

5. Mempelajari Masalah ( Learning Issues)

Pada tahap ini siswa diajak menjawab pertanyaan tentang, "Apa yang perlu diketahuai untuk memecahkan masalah yang dihadapi?" Setelah melakukan diskusi dan konsultasi, mereka melakukan penelaahan atau penelitian dan mengumpulkan informasi. Kemudian siswa melihat kembali ide-ide awal untuk menentukan mana yang masih dapat dipakai.

6. Menyusun Rencana Tindakan (Action Plan)

Pada tahaap ini mereka diajak mengembangkan sebuah rencana tindakan yang didasarkan atas hasil temuan mereka. Rencana tindakan ini berupa sesuatu (rencana) apa yang mereka akan lakukan atau berupa suatu saran-saran untuk memecahkan masalah.

7. Evaluasi

Evaluasi ini terdiri atas tiga hal: a) bagaimana siswa dan guru menilai produk (hasil akhir) proses, b) bagaimana mereka menerapkan tahapan PBL untuk bekerja melalui masalah, dan c) bagaimana siswa akan menyampaikan pengetahuan hasil pemecahakan masalah atau sebagai bentuk pertanggung jawaban mereka. 


\section{Observasi (Observing)}

Pada tahap observasi berisi tentang penjabaran rencana ke dalam tindakan dan mengamati jalannya tindakan. Dalam hal ini umpan balik segera dilakukan sebagai bahan untuk memodifikasi rencananya, kalau perlu diadakan rencana ulang manakala rencana awal kurang tepat. Sasaran pengamatan adalah keefektifan penerapan Problem Based Learning terhadap peningkatan sikap ilmiah siswa dalam pembelajaran IPA.

\section{Refleksi (reflecting)}

Tahap refleksi dilakukan untuk mengadakan upaya evaluasi yang dilakukan guru dalam Penelitian Tindakan Kelas. Refleksi dilakukan oleh peneliti dan obsever. Pada kegiatan refleksi ini ditelaah aspek-aspek mengapa, bagaimana, dan sejauh mana tindakan yang dilakukan mampu memperbaiki masalah secara bermakna dalam rangka meningkatkan sikap ilmiah siswa dengan pendekatan Problem Based Learning.

Demikianlah proses pembelajaran IPA dengan Pendekatan Problem Based Learning untuk meningkatkan sikap ilmiah siswa yang dilakukan dalam satu siklus. Siklus berikutnya dilakukan dengan langkah yang sama, namun tidak tertutup kemungkinan modifikasi berdasarkan hasil refleksi. Dengan kata lain, kekurangan dan kelemahan yang ditemui dalam satu siklus dijadikan sebagai bahan perencanaan untuk siklus berikutnya.

\section{Kriteria Keberhasilan Tindakan}

Kriteria merupakan, patokan untuk menentukkan keberhasilan suatu kegiatan atau program. Sesuai dengan karakteristik penelitian tindakan, keberhasilan dalam penelitian ini diliputi adanya perubahan-perubahan ke arah peningkatan yaitu peningkatan pada sikap ilmiah siswa. Kriteria keberhasilan tindakan dalam ini adalah jika minimal $75 \%$ siswa yang mengikuti proses pembelajaran IPA dalam sikap ilmiah dapat memperoleh nilai minimal 70.

Prosentase keberhasilan tersebut diperoleh dari jumlah siswa yang memperoleh nilai $\geq 70$ dibagi dengan jumlah siswa seluruhnya.

\section{Prosentase $\quad$ Jumlah siswa yang memperoleh nilai $\geq 70 \times 100 \%$ Keberhasilan jumlah siswa seluruhnya}




\section{Hasil Penelitian}

1. Kondisi Awal

Pada kondisi awal, proses pembelajaran dilaksanakan dengan pendekatan konvensional, yakni pembelajaran berpusat pada guru. Hal itu mendukung kondisi siswa pasif yang menyebabkan lemahnya sikap ilmiah mereka. Untuk lebih jelasnya dapat dilihat data yang diperoleh dari pengamatan kondisi awal sebelum dilakukan tindakan. Data yang diperoleh dapat dilihat pada tabel di bawah ini:

Tabel Hasil Pengamatan Sikap Ilmiah Siswa Pada Kondisi Awal

\begin{tabular}{|c|c|c|c|c|c|c|}
\hline No & $\begin{array}{c}\text { Kelas } \\
\text { Interval }\end{array}$ & $\mathbf{F}$ & $\%$ & $\mathbf{F k}$ & $\%$ & $\begin{array}{c}\text { Rata-rata } \\
\text { kelas }\end{array}$ \\
\hline 1 & $76-82$ & 0 & $0 \%$ & 0 & $0 \%$ & \multirow{9}{*}{51,93} \\
\hline 2 & $69-75$ & 4 & $25 \%$ & 4 & $25 \%$ & \\
\hline 3 & $62-68$ & 1 & $6,25 \%$ & 5 & $31,25 \%$ & \\
\hline 4 & $55-61$ & 0 & $0 \%$ & 5 & $31,25 \%$ & \\
\hline 5 & $48-54$ & 5 & $31,25 \%$ & 10 & $62,5 \%$ & \\
\hline 6 & $41-47$ & 1 & $6,25 \%$ & 11 & $68,75 \%$ & \\
\hline 7 & $34-40$ & 3 & $18,75 \%$ & 14 & $87,5 \%$ & \\
\hline 8 & $27-33$ & 2 & $12,5 \%$ & 16 & $100 \%$ & \\
\hline \multicolumn{2}{|c|}{ Jumlah } & 16 & $100 \%$ & & & \\
\hline
\end{tabular}

Berdasarkan tabel di atas, pada kondisi awal terdapat 4 siswa yang mencapai KKM. Jika dipersentasekan sebesar 25\%. Dari tabel nampak juga bahwa nilai di atas rata-rata yang dicapai adalah 51,93. Hal ini menunjukkan bahwa sikap ilmiah siswa pada umumnya masih rendah.

Gambaran sikap ilmiah siswa pada kondisi awal divisualisasikan dengan histogram di bawah ini:

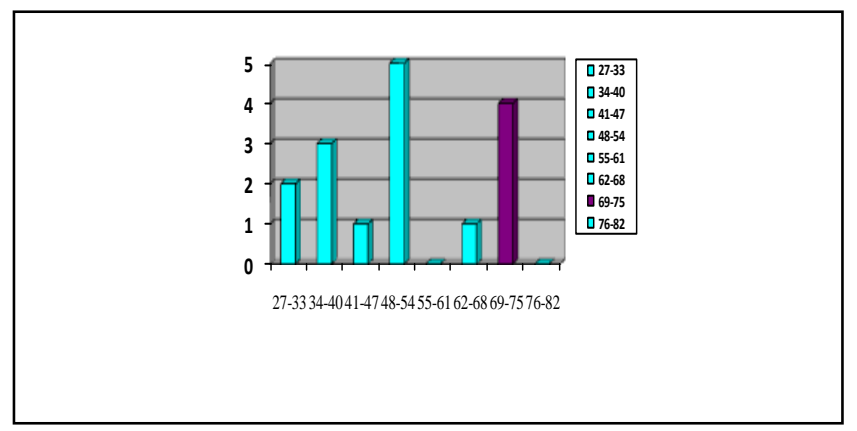

2. Siklus Pertama

Gambar Histogram Kemampuan Sikap Ilmiah Pada Kondisi Awal 
Data yang diperoleh pada kondisi awal dijadikan sebagai acuan dalam melaksanakan tindakan pada siklus pertama. Adapun kegiatan yang dilakukan pada siklus pertama adalah sebagai berikut :

a. Perencanaan

Sebelum melakukan tindakan pada siklus I, peneliti menyiapkan:

1) Media pembelajaran berupa gambar katrol, orang yang sedang beraktivitas mencabut paku, dan memasukkan beras ke bak truk, serta tangga

2) Alat peraga berupa pembuka tutup botol, gunting, skrup, pinset, steples, obeng, dan pembuka tutup kaleng

3) Lembar Kerja Siswa (LKS)

4) Lembar observasi sikap ilmiah siswa dan penerapan PBL

5) Kertas berupa gambar bintang, lampu, globe, awan, dan "smile”. Kertas gambar itu digunakan untuk memudahkan penilaian guru, khususnya aspekaspek dari sikap ilmiah yang dirasa penting bagi guru. Jika siswa bertanya akan mendapatkan gambar lampu, menjawab pertanyan mendapat gambar bintang, menguraikan argumen mendapat gambar globe, menemukan temuan baru mendapat gambar awan, dan perhatian pada obyek mendapat gambar "smile".

b. Tindakan

Siklus I terdiri dari tiga pertemuan. Setiap pertemuan berlangsung selama 70 menit. Langkah-langkah tindakan yang dilaksanakan adalah sebagai berikut.

1) Penyampaian ide (Ideas)

Pada langkah ini siswa diajak keluar kelas. Mereka secara individual mencari contoh alat atau benda yang termasuk pesawat sederhana. Pada umumnya siswa mampu menemukan lebih dari lima contoh alat peswat sederhana, seperti sapu, gunting, tongkat, kerekan bendera, dan katrol pada sumur timba. Hasilnya dicatat di kertas yang sudah disediakan oleh guru. Secara bersama-sama, guru dan siswa membahasnya. Kemudian dilakukan curah pendapat (brainstorming) dengan bimbingan guru. Kegiatan ini bertujuan untuk memeriksa pengetahuan awal siswa. 
Berdasarkan hasil kegiatan brainstorming, diketahui pada umumnya siswa memiliki pengetahuan awal yang cukup tentang materi pesawat sederhana. Hal tersebut dapat dilihat dari jawaban, komentar, dan argumen siswa. Mereka mengomentari jawaban teman lain yang kurang tepat, seperti sepeda motor, mobil, tas, dan atap sekolah. Mereka juga mampu memberikan argumen tentang perbedaan antara pesawat sederhana dengan pesawat rumit. Pada umumnya mereka juga sudah dapat menjawab pertanyaan tentang penggolongan dan kegunaan masing-masing alat pesawat sederhana. Dengan kata lain mereka sudah mampu mengantongi materi dasar tentang pesawat sederhana.

Setelah itu, kegiatan dilanjutkan dengan pemberian feedback dari guru. Feedback dilakukan agar tidak terjadi miss konsepsi pada siswa dalam materi pesawat sederhana.

Kegiatan selanjutnya, guru membagikan alat peraga dan beberapa contoh gambar kepada siswa. Guru mempersilahkan beberapa siswa mempresentasikan di depan kelas. Tujuannya untuk lebih memahamkan siswa tentang materi yang sedang dibahas. Guru memberikan pertanyaan arahan tentang contoh alat pesawat sederhana yang terdapat di ruang kelas. Guru menyajikan studi kasus dari penemuan siswa tersebut. Kemudian guru membahasnya dengan siswa.

Setelah kegiatan itu, guru menyajikan masalah dalam bentuk lembar kerja yang sudah disusun oleh guru untuk dibahas siswa secara berkelompok. Masalah yang disajikan ada tiga, yaitu; (a) jalan pegunungan yang berkelok-kelok, (b) seorang anak yang sedang membuka tutup botol dengan tangan, dan (c) seseoarang yang sedang mendorong batu besar dengan tangan.

2) Penyajian fakta yang diketahui (Known Facts)

Pada langkah ini, guru membagi siswa menjadi empat kelompok. Setiap kelompok terdiri dari empat siswa. Langkah berikutnya, siswa diajak mendata sejumlah fakta pendukung sesuai dengan masalah yang telah diberikan. Hasil pendataan tersebut ditulis pada lembar kerja yang telah disediakan.

3) Mempelajari Masalah (Learning Issues)

Pada tahap ini, siswa mendiskusikan masalah-masalah yang sudah disajikan untuk dilakukan identifikasi solusi pemecahannya atau hipotesis. Kemudian 
dengan bimbingan guru, siswa melakukan penelaahan dan pengumpulan informasi.

4) Menyusun Rencana Tindakan (Action Plan)

Pada langkah ini, siswa diajak mengembangkan sebuah rencana tindakan yang didasarkan atas hipotesis mereka. Siswa melakukan rencana tindakan ini dengan melakukan diskusi kelompok untuk memilih beberapa identifikasi pemecahan masalah untuk mereka pilih atau ajukan.

5) Evaluasi

Pada tahap ini, guru dan siswa membahas hasil kerja siswa secara bersamasama. Guru memberikan penjelasan dan penilaian tetang hasil kerja mereka. Kemudian siswa diberi kesempatan untuk bertanya jika ada sesuatu yang belum paham.

\section{Hasil Tindakan Siklus I}

Pada tindakan siklus I, pengamatan sikap ilmiah siswa dan penerapan Problem Based Learning dilaksanakan selama proses pembelajaran berlangsung. Pengamatan dilakukan dengan menggunakan lembar observasi.

1) Hasil analisis data kinerja guru

Hasil analisis terhadap data kinerja guru, menunjukkan hal-hal sebagai berikut. Pertama, pada tahap penyajian pembelajaran, (a) Perumusan masalah sudah bagus. Perumusan masalah yang sudah dirancang oleh guru dalam rencana pelaksanaan pembelajaran sudah dilakukan dengan runtut sesuai yang direncanakannya; (b) dalam pemberian bimbingan oleh guru melalui pertanyaan arahan untuk memahami permasalahan yang disajikan masih kurang. Pemberian pertanyaan arahan kurang sesuai dengan masalah yang sedang dibahas dalam materi tersebut. Hal itu menyebabkan pertanyaan tidak dipahami dan siswa lebih memilih bermain-main daripada fokus dalam pelajaran. Kedua, tahap pemodelan, (a) Rancangan observasi sudah baik. Lembar observasi sudah disiapkan ketika pembelajaran akan dilakukan. Hanya saja percobaan belum disiapkan sehingga pada siklus I percobaan tidak ada. Yang terjadi siswa mempresentasikan alat peraga, itupun jumlahnya sedikit yang seharusnya dimungkinkan bisa lebih bervariasi. Sedangkan pada siswa perancangan suatu kegiatan observasi masih 
belum berjalan dengan baik. Hal itu terlihat pada sebagian kelompok masih ada yang tidak merancang kegiatan tersebut dan mengerjakannya kurang sungguhsungguh; (b) pada keintensifan bimbingan guru saat merancang observasi/percobaan yang dilakukan siswa masih perlu ditingkatkan. Seperti yang sudah dijelaskan sebelumnya karena masih terdapat kelompok yang mengerjakannya tidak sungguh-sungguh yaitu tanpa rancangan kegiatan; Ketiga, pemeriksaan, (a) kegiatan pengumpulan data analisis melalui kegiatan-kegiatan observasi/percobaan yang dirancang oleh guru, sudah dilakukan oleh siswa cukup baik walaupun masih ada sebagian anak yang masih belum merespon kegiatan tersebut; (b) kegiatan pengorganisasian dan pencatatan data analisis masih perlu banyak bimbingan dari guru. Pengorganisasian kondisi pada kegiatan tersebut juga masih kurang. Hal tersebut dikarenakan masih ada beberapa anak yang kurang berpartisipasi. Mereka lebih memilih untuk bermain-main. Keempat, pengembangan pembelajaran, (a) keterlibatan siswa dalam presentasi dan diskusi masih kurang, karena jika ada salah satu kelompok mempresentasikan hasil tugasnya, kelompok lain kurang merespon dan tidak aktif untuk memberikan tanggapan. Keterlibatan guru dalam presentasi dan diskusi masih kurang intensif dalam melakukan bimbingan serta kurang managable dalam pengkondisian kelas sehingga suasana kelas masih sedikit gaduh; (b) keterlibatan siswa dan guru dalam menyusun kesimpulan pada siklus I belum terlaksana dengan maksimal karena guru sering lupa untuk melakukan kesimpulan; (c) pada pengembangan permasalahan guru masih kurang dalam mengembangkannya. Guru sering terpaut pada buku.

2) Gambaran Aktivitas dan Hasil Analisis Data Sikap Ilmiah Sisiwa

a) Gambaran Aktivitas Sikap Ilmiah Sisiwa pada Siklus I

Gambaran aktivitas sikap ilmiah siswa pada siklus I yaitu diawali dengan guru memberi pertanyaan arahan tentang definisi pesawat sederhana. Dengan adanya pertanyaan arahan dari guru, sikap ilmiah mereka terlihat dengan rasa ingin tahu mereka yang ditandai oleh beberapa siswa menjawab pertanyaan tersebut, dan siswa yang lain memperhatikannya. Indikator lain dari sikap ingintahu siswa muncul ketika guru mengajak keluar kelas dengan 
menginstruksikan siswa secara individual mencari contoh pesawat sederhana. Terekam siswa menanyakan setiap langkah kegiatan, terlibat aktif dalam proses pembelajaran, dan perhatian pada obyek. Perhatian pada obyek disini, siswa memperhatikan instruksi guru dengan melakukan tugas tersebut.

Aspek pada sikap penemuan siswa muncul, ketika guru menyajikan tiga masalah yang dikemas dalam bentuk lembar kerja siswa. Kelas dibagi menjadi 4 kelompok setiap kelompok terdiri dari 4 siswa. Siswa mengerjakan tugas tersebut dalam bentuk kelompok dengan berdiskusi tentang masalah yang sudah disajikan. Indikator dari sikap penemuan yaitu menggunakan fakta-fakta untuk memperoleh data konklusi muncul ketika siswa menguraikan hal itu yang berasal dari hasil pengamatan mereka ketika mereka diajak keluar kelas, info baik dari guru, catatan, dan buku serta pengamatan di dalam kelas. Fakta-fakta tersebut kemudian diformulasikan oleh siswa menjadi identifikasi-identifikasi solusi pemecahan masalah atau hipotesis. Hipotesis inilah yang yang menjadi temuan mereka. Dari hasil temuan mereka kemudian dianalisis untuk menetukan hasil solusi yang terbaik dari mereka. Kemudian mereka menunjukkan hasil laporan temuan mereka kepada guru dan kelompok lain yang ditulis pada LKS. Setelah itu dipresentasikan, sementara kelompok lain memberikan komentar dan pendapatnya.

Pada sikap berpikir kritis siswa muncul ketika siswa membuktikan suatu kebenaran dengan menjelaskan salah satu contoh benda yang ada di sekitar mereka bahwa benda itu termasuk pesawat sederhana. Dan ketika siswa melakukan percobaan, di dalam proses tersebut ada beberapa siswa yang menyakan setiap perubahan / hal baru pada objek yang sedang dikerjakan di dalam kegiatan percobaan. Kemudian data-data yang terkumpul oleh beberapa siswa ada yang tidak mengabaikan data tersebut meskipun kecil dengan mempertimbangkan sebagai hipotesis sebelum dibuktikan kebenarannya.

Pada sikap teguh pendirian siswa muncul ketika diskusi dan percobaan berlangsung. Siswa yang mempunyai sikap teguh pendirian dalam menjawab pertnyaan atau memtuskan suatu alternatif jawaban tidak ikut-ikutan pendapat teman dan tidak plin-plan dalam mengambil suatu keputusan. 
b) Hasil Analisis Data Sikap Ilmiah Sisiwa

Hasil analisis data sikap ilmiah siswa, yang diperoleh dalam kegiatan pembelajaran siklus I selengkapnya dapat dilihat pada tabel dibawah ini.

Tabel Distribusi Frekwensi Nilai Sikap Ilmiah Siswa Pada Siklus I

\begin{tabular}{|c|c|c|c|c|c|c|}
\hline No & Kelas Interval & $\mathbf{F}$ & $\%$ & fk & $\%$ & $\begin{array}{c}\text { Rata-rata } \\
\text { kelas }\end{array}$ \\
\hline 1 & $84-88$ & 0 & $0 \%$ & 0 & $0 \%$ & \multirow{10}{*}{66} \\
\hline 2 & $79-83$ & 2 & $12,5 \%$ & 2 & $12,5 \%$ & \\
\hline 3 & $74-78$ & 3 & $18,75 \%$ & 5 & $31,25 \%$ & \\
\hline 4 & $69-73$ & 4 & $25 \%$ & 9 & $56,25 \%$ & \\
\hline 5 & $64-68$ & 2 & $12,5 \%$ & 11 & $68,75 \%$ & \\
\hline 6 & $59-63$ & 0 & $0 \%$ & 11 & $68,75 \%$ & \\
\hline 7 & $54-58$ & 1 & $6,25 \%$ & 12 & $75 \%$ & \\
\hline 8 & $49-53$ & 2 & $12,5 \%$ & 14 & $87,5 \%$ & \\
\hline 9 & $44-48$ & 2 & $12,5 \%$ & 16 & $100 \%$ & \\
\hline & Jumlah & 16 & $100 \%$ & & & \\
\hline
\end{tabular}

Dari tabel di atas dapat dideskripsikan bahwa pada siklus I sebanyak $56,25 \%$ (9 siswa) yang mencapai KKM. Selain itu juga nampak bahwa nilai ratarata yang dicapai baru 66 .

Tabel di atas menunjukkan target yang ditetapkan belum tercapai, sehingga dapat dikatakan sikap ilmiah siswa masih rendah. Walaupun demikian pada tahap ini sikap ilmiah siswa sudah mengalami peningkatan bila dibandingkan dengan kondisi awal.

Apabila divisualisasikan dalam bentuk histogram, maka dapat dicermati pada gambar di bawah ini:

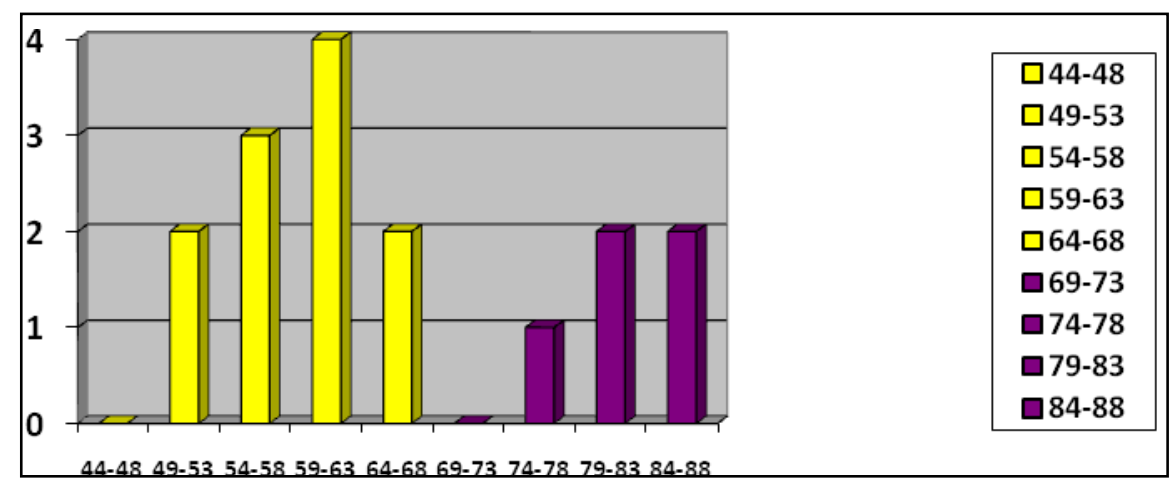

Gambar Histogram Kemampuan Sikap Ilmiah Siswa Pada Siklus I

c) Observasi 
Hasil observasi menunjukkan bahwa proses belajar mengajar belum berjalan secara maksimal. Hal ini ditunjukkan dengan situasi kelas yang masih belum kondusif. Dalam pembelajaran masih ada sebagian siswa yang membuat gaduh di dalam kelas dan mengganggu temannya dengan bermain-main ikat pinggang punya temannya, mencubit dan menimpuk, serta bermain HP milik temannya. Walaupun guru sudah menyita mainan mereka, tetapi tetap saja ada anak yang bandel dengan membuat kegaduhan kembali.

Kondisi yang belum kondusif juga terlihat pada beberapa kelompok. Ada beberapa yang bermalas-malasan dalam mengerjakan tugas yang diberikan dalam bentuk lembar kerja. Mereka sengaja tidak menjawab pertannyaan dengan mengosongi jawaban. Bahkan mereka lebih memilih bercerita dengan teman sekelompoknya. Setelah dilakukan wawancara hal tersebut disebabkan beberapa siswa tidak menyukai penyusunan soal yang diberikan guru. Siswa menuturkan bahwa penyusunan soal tersebut terlalu sulit dipahami dan baru pertama kali mendapatkan bentuk soal seperti itu sehingga mereka merasa bingung dan malas untuk mengerjakannya. Namun demikian hasil pembelajaran sudah memperlihatkan adanya kemajuan. Hal ini dapat dilihat dari perolehan nilai sikap ilmiah mereka. Pada kondisi awal terdapat 4 siswa yang mencapai nilai KKM. Jika dipersentasekan sebesar 25\%. Sedangkan pada siklus I terdapat 9 siswa. Jika dipersentasekan sebesar $56 \%$.

d) Refleksi

Berdasarkan hasil pengamatan, pembelajaran yang diterapkan belum sepenuhnya menarik perhatian siswa. Kepasifan sebagian siswa dalam menguraikan dan mengemukakan pendapat menjadi situasi yang agak dominan dalam pembelajaran pada siklus I. Ada juga faktor lain yang mendukung dilakukannya perbaikan, yaitu perencanaan dan pengelolaan pembelajaran yang dilakukan oleh guru belum berhasil. Terekam dari hasil kinerja guru bahwa pemberian bimbingan melalui pertanyaan arahan untuk memahami permasalahan yang disajikan masih kurang. Pemberian pertanyaan arahan kurang sesuai dengan masalah yang sedang dibahas dalam materi tersebut. Keintensifan bimbingan guru saat merancang observasi/percobaan yang dilakukan siswa masih perlu 
ditingkatkan. Masih terdapat kelompok yang mengerjakannya tidak sungguhsungguh yaitu tanpa rancangan kegiatan. Pengorganisasian kelas oleh guru masih kurang managable. Masih banyak siswa yang kurang berpartisipasi. Mereka lebih memilih untuk bermain-main.

Fasilitas yang berupa alat peraga dan media dapat dikatakan belum sesuai yang diharapkan. Media yang disajikan hanya berupa gambar. Hal tersebut mengakibatkan keterbatasan pengalaman siswa. Mereka hanya mengamati gambar sehingga lama-kelamaan menjadi jenuh. Alat peraga yang seharusnya dapat memungkinkan lebih bervariasi, pada siklus I hanya sedikit saja yang disajikan. Hal itu menyebabkan kurang memberikan stimulus terhadap keaktifan dan pemahaman siswa. Dengan demikian, untuk tindakan berikutnya, anak diajak keluar lagi seperti pada pertemuan pertama dalam siklus I. Yang membedakan pada siklus I, anak hanya mencari secara individu contoh alat atau benda yang berkaitan dengan pesawat sederhana. Sedangkan tindakan siklus selanjutnya, anak diajak keluar dengan bimbingan dan arahan beserta penjelasan dari guru mengenai pesawat sederhana.

\section{Siklus Kedua}

Data hasil pengamatan siklus I belum memperlihatkan peningkatan yang berarti. Masih terdapat 7 (44\%) siswa yang belum mencapai KKM. Dengan demikian pada siklus II ini peneliti melakukan kegiatan sebagai berikut.

a. Perencanaan

Untuk menindaklanjuti dari hasil refleksi siklus II ini peneliti mempersiapkan hal-hal sebagai berikut :

1) Alat peraga yang lebih bervariasi. Jenisnya masih sama dalam benda konkret. Ada bebrapa alat peraga yang disajikan dalam bentuk audio visual yang dipaparkan lewat video dengan bantuan LCD proyektor.

2) Lembar Kerja Siswa di susun untuk memudahkan siswa memahaminya

3) Lembar observasi sikap ilmiah siswa dan penerapan PBL

4) Kertas berupa gambar bintang, lampu, globe, awan, dan "smile”. Kertas gambar itu digunakan untuk memudahkan penilaian guru, khususnya aspekaspek dari sikap ilmiah yang dirasa penting bagi guru. 


\section{b. Tindakan Siklus II}

Siklus II terdiri dari dua pertemuan. Setiap pertemuan berlangsung selama 70 menit. Pada siklus II tindakan dikemas agar lebih menarik perhatian siswa dan sesuai pada refleksi siklus I. Pembelajaran menggunakan media audio visual dalam bentuk video yang diproduksi oleh peneliti dan CD pembelajaran interaktif yang dapat dipakai untuk pembelajaran klasikal. Secara rinci tindakan yang dilakukan sebagai berikut:

1) penyampaian ide (Ideas)

Pada langkah ini, siswa diajak keluar kelas untuk melihat langsung alat pesawat sederhana yang terdapat di lingkungan sekolah dengan bimbingan, arahan, dan penjelasan dari guru. Hal itu bertujuan me-recall pengetahuan dan melibatkan siswa ke dalam dunia nyata.

Selanjutnya, siswa kembali ke kelas dan guru membagi kelas menjadi empat kelompok. Setiap kelompok terdiri dari empat anak. Pembagian kelompok masih sama dengan siklus II karena dirasa tidak bermasalah dan pembagiannyapun cukup adil dan seimbang.

Kemudian masing-masing kelompok mendapat alat peraga yang akan dipresentasikan di depan kelas. Kelompok lain memberikan tanggapan. Sementara itu guru membimbing jalannya presentasi dan diskusi serta memberikan feedback dan penilaian hasil kerja siswa.

2) Penyajian fakta yang diketahui (Known Facts)

Pada langkah ini, guru menyajikan masalah dengan bantuan video, CD pembelajaran, dan lembar kerja. Siswa mendiskusikan maslah-masalah tersebut. Kemudian mendata sejumlah fakta pendukung sesuai dengan masalah yang telah diajukan. Hasil ditulis pada lembar kerja yang sudah disediakan.

3) Mempelajari Masalah ( Learning Issues)

Pada langkah ini siswa mengidentifikasi solusi pemecahannya. Sesudah itu mereka melakukan penelaahan dan pengumpulan informasi. Penelaahan dilakukan dengan melakukan percobaan menggunakan alat peraga yang sudah disediakan. Siswa melakukan percobaan berkelompok dengan bimbingan dan arahan dari guru. Tujuannya adalah untuk membuktikan kebenaran hipotesis yang sudah 
mereka list pada lembar kerja. Pengumpulan informasi dilakukan dengan menggunakan sumber-sumber informasi yang ada di sekitar siswa dan ada beberapa yang sudah disediakan seperti sumber bacaan, materi, dan catatan dari guru.

4) Menyusun Rencana Tindakan (Action Plan)

Siswa diajak mengembangkan sebuah rencana tindakan dengan beberapa pemecahan masalah yang didasarkan pada hasil percobaan dan pencarian informasi dari berbagai sumber. Dari hasil pengembangan tersebut, siswa melakukan diskusi kelompok untuk menentukan beberapa pemecahan masalah untuk mereka pilih atau ajukan.

5) Evaluasi

Pada tahap ini, setiap kelompok menguraikan hasilnya sementara kelompok lain memberikan tanggapan. Guru membimbing jalannya diskusi, memberikan penjelasan, dan penilain. Kemudian siswa diberi kesempatan untuk menanyakan sesuatu yang mereka belum paham. Guru membimbing siswa untuk membuat kesimpulan.

Hasil Tindakan Siklus II

Pada siklus II, pengamatan pembelajaran dilaksanakan sama seperti pada tahap sebelumnya. Pengamatan ini dilakukan untuk mengetahui perkembangan kemampuan sikap ilmiah siswa dan kinerja guru dalam pembelajaran IPA.

1) Hasil analisis data kinerja guru

Hasil analisis data kinerja guru, menunjukkan hasil sebagai berikut. Pertama, pada tahap penyajian pembelajaran, (a) Langkah pembelajaran dalam perumusan masalah sudah bagus seperti pada siklus I. Perumusan masalah yang sudah dirancang oleh guru dalam rencana pelaksanaan pembelajaran sudah dilakukan dengan runtut sesuai yang direncanakannya; (b) Pemberian bimbingan oleh guru melalui pertanyaan arahan untuk memahami permasalahan yang disajikan sudah bagus. Guru sudah intensif dalam memberikan pertanyaan arahan dibanding pada siklus I. Pertanyaan arahan yang dianjurkan tidak terlalu luas, komunikatif dan jelas sehingga anak dapat memahaminya. Kedua, pada tahap pemodelan, (a) Perancangan suatu kegiatan observasi/percobaan sudah dirancang 
dengan baik. Hal itu dibuktikan lembar observasi dan alat percobaan untuk setiap kelompok sudah disiapkan ketika pembelajaran akan dilaksanakan. Sedangkan pada siswa, perancangan observasi/percobaan sudah berjalan dengan baik. Hal itu terlihat pada semua kelompok sudah merancang kegiatan tersebut dan mengerjakannya dengan sungguh-sungguh; (b) Keintensifan bimbingan guru saat merancang observasi/percobaan yang dilakukan siswa sudah baik. Frekwensinya meningkat dibanding pada siklus I; Ketiga, pemeriksaan, (a) Kegiatan pengumpulan data analisis melalui kegiatan-kegiatan observasi/percobaan yang dirancang oleh guru, sudah dilakukan siswa dengan baik. Semua kelompok bekerjasama dan semua berpartisipasi dalam kelompoknya masing-masing. Keantusiasan siswa dalam melakukan percobaan menciptakan kondisi siswa senang dan aktif. Semua fokus pada tugasnya. Hasil percobaan tersebutpun dikerjakan dengan cepat dan tepat; (b) Kegiatan pengorganisasian dan pencatatan data analisis sudah baik, karena sudah semua kelompok bekerjasama dan semua berpartisipasi dalam kelompoknya masing-masing sehingga menciptakan kondisi yang kondusif dibanding pada tahap sebelumnya. Keempat, pengembangan pembelajaran, (a) Keterlibatan siswa dan guru dalam presentasi dan diskusi sudah bagus. Semua kelompok sudah berpartisipasi aktif walau masih ada dua anak yang masih kurang aktif. Dua anak tersebut memang dari pengamatan pada kondisi awal sampai siklus II, kemampuannya baik dari sikap ilmiah maupun kognitif terlihat jelas tertinggal dengan teman lainnya. Hal itu nampak pada hasil pengamatan dari kondisi awal sampai siklus II, mereka nilainya paling rendah dibanding teman lainnya. Bedasarkan wawancara dengan guru dan siswa lainnya, kondisi kedua anak tersebut memang demikian. Jika dilihat dari kerja otak memang jalannya sangat lambat dibanding siswa lainnya. Walau demikian ada peningkatan sedikit dari kondisi awal sampai siklus II. Pembelajaran pada siklus II sudah ada peningkatan dibanding tahap sebelumnya dan peran guru sudah baik dengan memberikan bimbingan dan arahan dalam jalannya presentasi dan diskusi; (b) Keterlibatan siswa dan guru dalam menyusun kesimpulan pada siklus I sudah terlaksana dan dilaksanakan cukup baik dibanding pada tahap sebelumnya yang sering lupa dalam memberikan kesimpulan dalam pembelajaran; (c) Pada 
pengembangan permasalahan sudah baik dalam mengembangkannya. Guru sudah memberikan permasalahan yang terjadi pada masyarakat dengan memperlihatkan video yang dirancang sendiri. Berdasarkan uraian di atas, kinerja guru menerapkan Problem Based Learning dalam pembelajaran IPA sudah terlihat adanya peningkatan yang baik.

2) Gambaran aktivitas dan hasil analisis data sikap ilmiah siswa

a. Gambaran aktivitas dan Hasil analisis data sikap ilmiah sisiwa pada siklus II

Gambaran aktivitas sikap ilmiah siswa pada siklus II yaitu diawali dengan guru memberi pertanyaan arahan tentang contoh-contoh pesawat sederhana dan perbedaannya dengan pesawat rumit. Dengan adanya pertanyaan arahan dari guru, sikap ilmiah mereka terlihat dengan rasa ingin tahu mereka yang ditandai oleh beberapa siswa menjawab pertanyaan tersebut, dan siswa yang lain memperhatikannya. Indikator lain dari sikap ingintahu siswa muncul ketika siswa mengerjakan lembar kerja (tugas) secara kelompok. Terekam beberapa siswa menanyakan setiap langkah kegiatan, terlibat aktif dalam proses pembelajaran dengan melakukan segala yang diinstruksikan oleh guru, dan perhatian pada obyek. Perhatian pada obyek disini, siswa memperhatikan instruksi guru dengan melakukan tugas tersebut.

Pada aspek sikap penemuan siswa muncul, ketika guru menyajikan tiga masalah yang dikemas dalam bentuk lembar kerja siswa dan audio visual. Kelas dibagi menjadi 4 kelompok setiap kelompok terdiri dari 4 siswa seperti pada siklus I. Siswa mengerjakan tugas tersebut dalam bentuk kelompok dengan berdiskusi tentang masalah yang sudah disajikan. Indikator dari sikap penemuan yaitu menggunakan fakta-fakta untuk memperoleh data konklusi muncul ketika siswa menguraikan hal itu yang berasal dari hasil pengamatan mereka ketika mereka diajak keluar kelas, info baik dari guru, catatan, dan buku serta pengamatan di dalam kelas. Fakta-fakta tersebut kemudian diformulasikan oleh siswa menjadi identifikasi-identifikasi solusi pemecahan masalah atau hipotesis. Hipotesis inilah yang yang menjadi temuan mereka. Dari hasil temuan mereka kemudian dianalisis untuk menetukan hasil solusi yang terbaik dari mereka dengan melakukan percobaan sebagai pembuktian dari temuan mereka. Kemudian 
mereka menunjukkan hasil laporan temuan mereka kepada guru dan kelompok lain yang ditulis pada LKS. Setelah itu dipresentasikan, sementara kelompok lain memberikan komentar dan pendapatnya.

Pada sikap berpikir kritis siswa muncul ketika siswa membuktikan suatu kebenaran dengan menjelaskan salah satu contoh benda yang ada di sekitar mereka bahwa benda itu termasuk pesawat sederhana baik benda yang disajikan secara konkret naupun dalam bentuk audio visual. Dan ketika siswa melakukan percobaan, di dalam proses tersebut ada beberapa siswa yang menyakan setiap perubahan / hal baru pada objek yang sedang dikerjakan di dalam kegiatan percobaan. Kemudian data-data yang terkumpul oleh beberapa siswa ada yang tidak mengabaikan data tersebut meskipun kecil dengan mempertimbangkan sebagai hipotesis sebelum dibuktikan kebenarannya.

Pada sikap teguh pendirian siswa muncul ketika diskusi dan percobaan berlangsung. Siswa yang mempunyai sikap teguh pendirian dalam menjawab pertnyaan atau memtuskan suatu alternatif jawaban tidak ikut-ikutan pendapat teman dan tidak plin-plan dalam mengambil suatu keputusan.

b. Hasil analisis data sikap ilmiah siswa

Hasil analisis data sikap ilmiah siswa, yang diperoleh dalam kegiatan pembelajaran siklus II selengkapnya dapat dilihat pada tabel 1. 3 dibawah ini.

Tabel Distribusi Frekwensi Nilai Sikap Ilmiah Siswa Pada Siklus II

\begin{tabular}{|c|c|c|c|c|c|c|}
\hline No & $\begin{array}{c}\text { Kelas } \\
\text { Interval }\end{array}$ & $\mathbf{F}$ & $\%$ & $\mathbf{f k}$ & $\%$ & $\begin{array}{c}\text { Rata-rata } \\
\text { kelas }\end{array}$ \\
\hline 1 & $89-95$ & 1 & $6,25 \%$ & 1 & $6,25 \%$ & \multirow{9}{*}{77,56} \\
\hline 2 & $82-88$ & 7 & $43,75 \%$ & 8 & $50 \%$ & \\
\hline 3 & $75-81$ & 3 & $\begin{array}{c}18,75 \\
\%\end{array}$ & 11 & $18,75 \%$ & \\
\hline 4 & $68-74$ & 2 & $12,5 \%$ & 13 & $81,25 \%$ & \\
\hline 5 & $61-67$ & 1 & $6,25 \%$ & 14 & $87,5 \%$ & \\
\hline 6 & $54-60$ & 2 & $12,5 \%$ & 16 & $100 \%$ & \\
\hline 7 & $47-53$ & 0 & $0 \%$ & 16 & $100 \%$ & \\
\hline 8 & $40-46$ & 0 & $0 \%$ & 16 & $100 \%$ & \\
\hline & Iumlah & 16 & $100 \%$ & & & \\
\hline
\end{tabular}


Dari tabel di atas dapat dideskripsikan bahwa pada siklus II menunjukkan bahwa sebanyak 81,25\% (13 siswa) yang mencapai KKM. Selain itu juga nampak bahwa nilai rata-rata yang dicapai 77,56 . Hal ini berarti pada tindakan siklus II mengalami peningkatan sikap ilmiah siswa secara signifikan. Secara umum bisa disimpulkan bahwa penerapan Problem Based Learning dapat meningkatkan sikap ilmiah siswa.

Apabila divisualisasikan dalam bentuk histogram, maka dapat dicermati pada gambar di bawah ini:

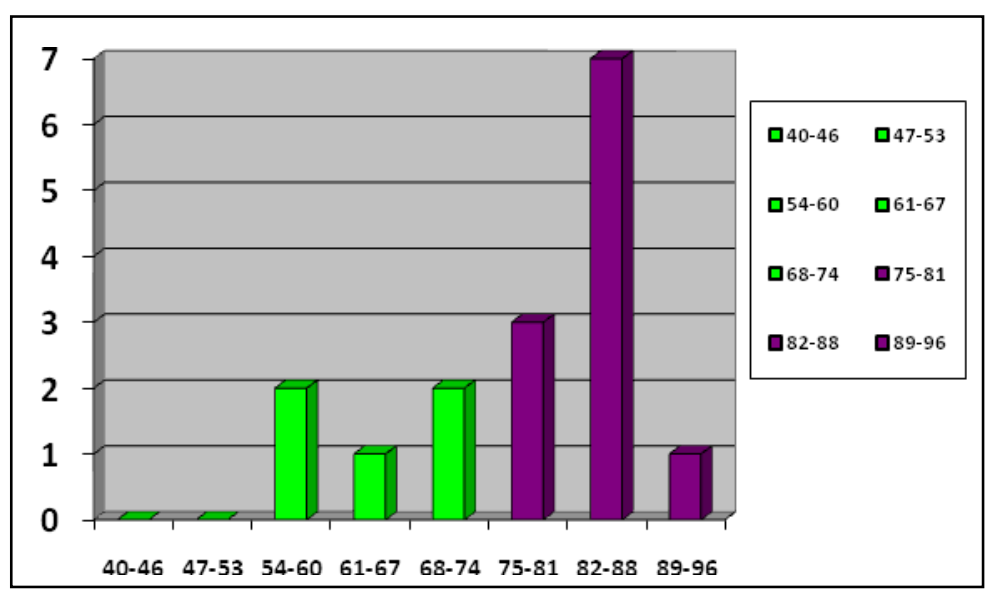

Gambar Histogram Kemampuan Sikap Ilmiah Siswa Pada Tahap II

Berdasarkan uraian di atas telah terlihat adanya peningkatan sikap ilmiah siswa dari kondisi awal samapai siklus II. Berikut ini akan disajikan tabel perbandingan hasil pengamatan kemampuan sikap ilmiah siswa dalam bentuk persentase dari kondisi awal samapi siklus II. Selengkapnya tabel dapat dilihat sebagai berikut.

Tabel Perbandingan Kemampuan Sikap Ilmiah Siswa dari kondisi awal sampai siklus II

\begin{tabular}{|c|c|c|c|}
\hline Nilai & Kondisi Awal & Siklus I & Siklus II \\
\hline $70<$ & $75 \%$ & $44 \%$ & $19 \%$ \\
\hline$>70$ & $25 \%$ & $56 \%$ & $81 \%$ \\
\hline
\end{tabular}

Dari tabel di atas nampak jelas bahwa telah terjadi peningkatan sikap ilmiah siswa secara signifikan. Terbukti pada kondisi awal siswa yang mencapai KKM sebanyak 25\%. Kemudian Pada siklus I mengalami peningkatan sebesar $31 \%$ 
menjadi 56\%. Pada siklus II mengalami peningkatan lagi $25 \%$ menjadi $81 \%$. Peningkatan tersebut terjadi karena pada siklus I dan II dilakukan tindakan dengan Menerapkan Problem Based Learning. Hal ini jelas bahwa penerapan Problem Based Learning dapat meningkatkan sikap ilmiah siswa dalam pembelajaran IPA.

Gambaran perbandingan kemampuan sikap ilmiah siswa dari kondisi awal sampai siklus II yang disajikan dalam bentuk presentase dapat divisualisasikan pada histogram di bawah ini:

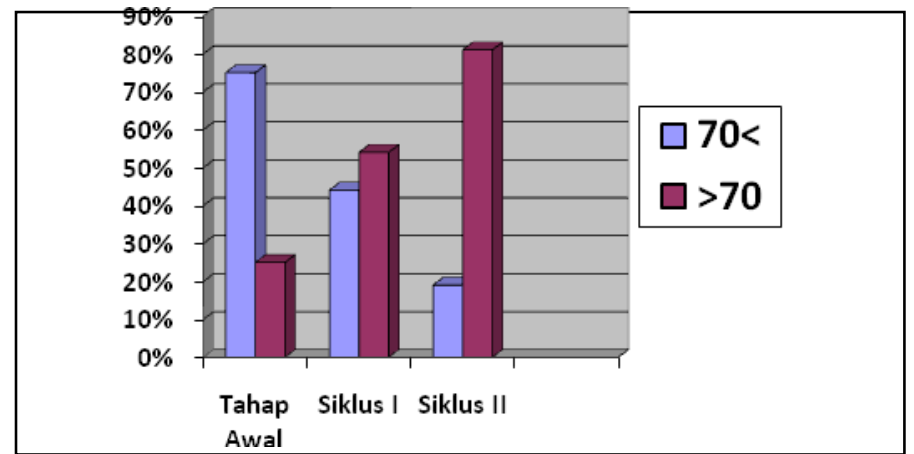

Gambar Histogram Perbandingan Kemampuan Sikap Ilmiah Siswa Pada Kondisi Awal sampai Tahap II

Di bawah ini juga akan disajikan tabel perbandingan aspek sikap ilmiah dari kondisi awal sampai siklus II. Tabel tersebut adalah sebagai berikut :

Tabel Jumlah Skor Pencapaian dan Prosentase Aspek Sikap Rata-Rata Kondisi Awal sampai Siklus II

\begin{tabular}{|l|l|c|c|c|c|c|c|}
\hline \multirow{2}{*}{ No } & \multirow{2}{*}{$\begin{array}{c}\text { Aspek Sikap } \\
\text { Ilmiah }\end{array}$} & \multicolumn{2}{|c|}{ Kondisi Awal } & \multicolumn{2}{c|}{ Siklus I } & \multicolumn{2}{c|}{ Iklus II } \\
\cline { 3 - 8 } & $\sum$ Skor & \% & $\sum$ Skor & \% & $\sum$ Skor & \% \\
\hline 1. & Ingain Tahu & 217 & $67 \%$ & 239 & $75 \%$ & 265 & $81 \%$ \\
\hline 2. & Penemuan & 186 & $46 \%$ & 270 & $67 \%$ & 300 & $75 \%$ \\
\hline 3. & Berpikir Kritis & 87 & $36 \%$ & 112 & $47 \%$ & 166 & $70 \%$ \\
\hline 4. & Teguh Pendirian & 140 & $58 \%$ & 147 & $61 \%$ & 190 & $80 \%$ \\
\hline
\end{tabular}

Dari tabel di atas menunjukkan adanya peningkatan setiap aspeknya dari kondisi awal samapi pada siklus II. Sikap ingin tahu siswa pada kondisi awal sebesar $67 \%$. Kemudian pada siklus I mengalami peningkatan sekitar $8 \%$ menjadi 75\%. Pada siklus II mengalami peningkatan lagi sekitar $6 \%$ menjadi $81 \%$. Begitu pula pada sikap penemua siswa pada kondisi awal sebesar $46 \%$. Kemudian pada siklus I meningkat sekitar $21 \%$ menjadi $67 \%$. Pada siklus II mengalami 
peningkatan lagi sekitar $8 \%$ menjadi $75 \%$. Pada Sikap kritis di kondisi awal sebesar $36 \%$. Kemudian pada siklus I meningkat sekitar 11\% menjadi 47\%. Pada siklus II mengalami peningkatan lagi sekitar 30\% menjadi 70\%. Begitu juga sikap teguh pendirian terlihat dari kondisi awal sebesar 58\%. Kemudian mengalami peningkatan sekitar 3\% menjadi 61\%. Pada siklus II mengalami peningkatan lagi sekitar 19\% menjadi $80 \%$. Hal ini membuktikan bahwa penerapan Problem Based Learning dapat meningkatkan sikap ilmiah siswa.

Gambaran perbandingan aspek sikap ilmiah siswa pada kondisi awal samapai siklus II dapat divisualisasikan sebagai berikut:

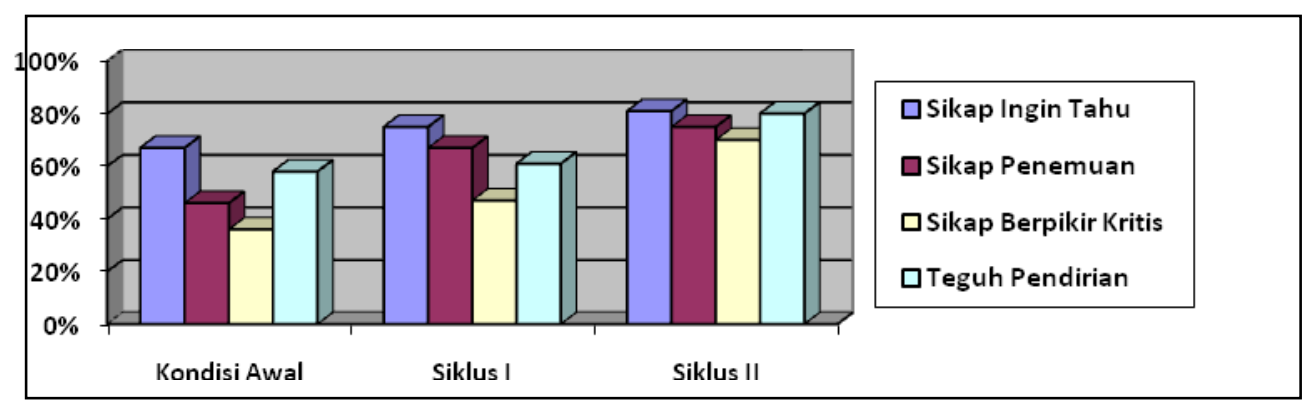

Histogram Kemampuan Sikap Ilmiah Siswa Pada Kondisi Awal dan Siklus I dan II

Berikut hasil evaluasi kerja kelompok siswa pada siklus I dan II, dapat dilihat pada tabel di bawah ini :

Tabel Nilai Evaluasi Kerja Kelompok

\begin{tabular}{|l|l|c|c|}
\hline No & Nama Kelompok & Siklus I & Siklus II \\
\cline { 3 - 4 } & & Nilai & Nilai \\
\hline 1 & Kuning & 93 & 81 \\
\hline 2 & Hijau & 80 & 100 \\
\hline 3 & Pink & 85 & 82 \\
\hline 4 & Biru & 89 & 100 \\
\hline \multicolumn{2}{|c|}{ Jumlah } & $\mathbf{3 4 7}$ & $\mathbf{3 6 3}$ \\
\hline \multicolumn{2}{|c|}{ Rata-rata } & $\mathbf{8 6 , 7 5}$ & $\mathbf{9 0 , 7 5}$ \\
\hline
\end{tabular}

Dari tabel di atas menunjukkan adanya peningkatan kognitif siswa. Pada siklus I terlihat sudah mencapai KKM dengan rata-rata kelas 86,75. Pada siklus II mengalami peningkatan dengan rata-rata kelas 90,75. Hal ini dapat disimpulkan bahwa penerepan Problem Based Learning tidak mengacuhkan pada ranah kognitif atau dapat dikatakan membawa dampak baik terhadap pengetahuan siswa. 
Gambaran perbandingan nilai kognitif siswa pada siklus I dan II dapat divisualisasikan sebagai berikut:

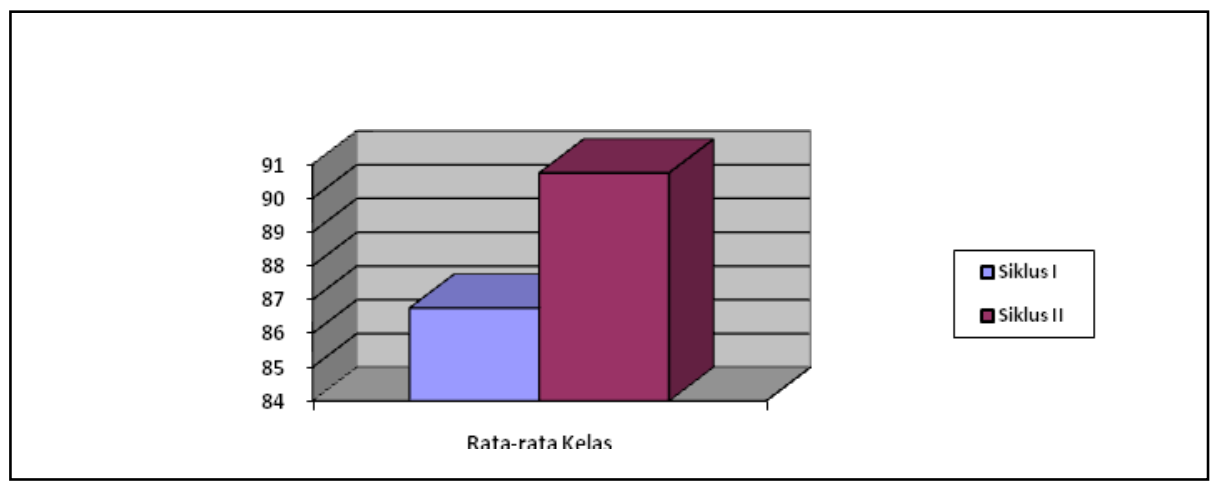

Gambar Histogram Perbandingan Nilai Kognitif Siswa Pada Siklus I dan II

c. Observasi

Pada siklus II, situasi pembelajaran berlangsung kondusif. Siswa merasa senang dengan pembelajaran yang diterapkan. Setiap kelompok sudah menunjukkan sikap ingintahu, berpikir kritis, sikap penemuan, dan sikap teguh pendirian. Setiap aspek dari sikap ilmiah mengalami peningkatan dari kondisi awal sampai siklus II (lihat tabel 5 dan gambar 6). Hal tersebut dikarenakan pembelajaran yang diterapkan oleh guru sudah tepat yaitu memberikan pengalaman langsung pada siswa dan siswa lebih peka terhadap permasalahan nyata (a real world problems), khususnya tentang pesawat sederhana. Hasil terakhir menunjukkan bahwa sikap ilmiah siswa meningkat dengan nilai tertinggi 89 dan terendah 40 .

d. Refleksi

Berdasarkan hasil pengamatan, situasi pembelajaran menunjukkan adanya peningkatan. Pada siklus I terdapat 9 anak yang mencapai KKM sebesar 56\%. Sedangkan pada siklus II terdapat 13 anak sebesar $81 \%$.

Penerapan Problem Based Learning dapat meningkatkan kemampuan sikap ilmiah siswa. Pembelajaran yang diterapkan lebih menarik perhatian siswa sehingga siswa lebih berkonsentrasi untuk mengikuti proses belajar mengajar.

Siswa merasa senang dengan pembelajaran yang diterapkan. Hal ini bisa dilihat dari antusias siswa dalam melaksanakan semua kegiatan baik di luar kelas 
maupun di dalam kelas, dari kegiatan mengamati, mengidentifikasi, mencatat, menganalisis, melakukan percobaan, diskusi, dan presentasi.

\section{Simpulan}

Berdasarkan hasil penelitian yang telah dikemukakan dapat disimpulkan sebagai berikut: pertama, hasil pengamatan proses pembelajaran setiap siklus mununjukkan jika Problem Based Learning dalam pembelajaran IPA mampu meningkatkan sikap ilmiah siswa. Kedua, penerapan Problem Based Learning, di samping dapat meningkatkan sikap ilmiah siswa, juga berdampak pada peningkatan kognitif siswa.

Berpijak dari beberapa kesimpulan tersebut, maka bagi para guru SD yang masih menerapkan pembelajaran konvensional mampu berupaya mengemas pembelajaran semenarik mungkin agar siswa senang belajar sehingga dapat dipastikan hasil yang didapat akan lebih baik dan siswa perlu diarahkan untuk melakukan kegiatan agar siswa aktif dalam pembelajaran. Selain itu dalam pembelajaran guru hendaknya berperan sebagai fasilitator dan motifator yang mampu menyediakan pengalaman belajar yang memungkinkan siswa bertanggungjawab dalam melakukan proses belajar. 


\section{Daftar Pustaka}

Bundu, Patta. 2006. Penilaian Keterampilan Proses dan Sikap Ilmiah Dalam pembelajaran Sains SD. Jakakarta : Departemen Pendidikan Nasional.

Depdikbud. 2008. Kurikulum Satuan Tingkat Pendidikan. Kebumen: Depdikbud.

Gallagher. 1997. Pembelajaran Berbasis Masalah (Problem Based Learning)dalamIPA.http:// edweb.sdsu.edu/clrit/learningtree/PBL/PBLadvantages.html.Tanggal akses: 26 januari 2010.

Setyosari, Punaji. 2009. Belajar Berbasis Masalah (Problem-Based Learning). http://tep.um.ac.id/berita-223-belajar-berbasis-masalah--problembasedlearning.html. Tanggal akses: 13 November 2009.

Samatowa, Usman. 2006. Bagaimana Membelajarkan IPA Di Sekolah Dasar. Jakarta : Departemen Pendidikan Nasional.

Undang-undang Republik Indonesia No 20, Tahun 2003

Undang-undang Republik Indonesia No 14, Tahun 2005 